\title{
Development of Asbestos-free Brake Pads Using Bamboo Leaves
}

\author{
Adekunle N. O. ${ }^{1}$, Oladejo K. A. ${ }^{2} *$, Kuye S. I. ${ }^{3}$ and Aikulola A. D. ${ }^{4}$ \\ ${ }^{1,3,4}$ Department of Mechanical Engineering, Federal University of Agriculture, Abeokuta, Nigeria \\ ${ }^{2}$ Department of Mechanical Engineering, Obafemi Awolowo University, Ile-Ife, Nigeria \\ *Corresponding Author: wolesteady@yahoo.com
}

https://doi.org/10.36263/nijest.2019.02.0126

\begin{abstract}
Asbestos-based brake pads are not desirable due to the carcinogenic nature of asbestos. Organic asbestos-free brake automotive brake pad produced from bamboo leaves was evaluated in this study. Ground bamboo leaves were sieved into sieve grades of 100, 200, and $350 \mu \mathrm{m}$. The sieved bamboo leaves particles were then combined with $15 \%$ steel dust, $10 \%$ graphite, $20 \%$ resin, Silicon Carbide varied five (5) times between 35-55\% and 0-20\% respectively for each sieve grade to make brake pads of different ratios. The mechanical properties (hardness, compressive strength, density, porosity, wear rate, and flame resistance) of the produced samples were investigated. The results showed that the finer the particle size of the bamboo leaves, the better the mechanical properties of the produced samples. The results of this work when compared with those of the commercial (asbestos based) brake pad showed they were in close agreement except for the wear rate and porosity property. Therefore, bamboo leaves could be used in the production of asbestos free brake pads if the wear rate and porosity properties of the produced samples could be improved.
\end{abstract}

Keywords: bamboo leaves, compressive strength, density, flame resistance, hardness, porosity, swell, wear

\subsection{Introduction}

Brake pads are important component of disc brakes used in automotive and other applications (Elakhame et al., 2014). Brake pads are steel backing plates with friction material bound to the surface that faces the disk brake rotor (Aigbodion et al., 2010). The part of the brake pad that makes contact with the rotor is called the friction lining which is a composite material of four main components comprising frictional additives which determine the frictional properties of the brake pads and comprise a mixture of abrasives and lubricants; reinforcing fibre or structural materials that provide strength e.g. metal, glass, kevlar, and carbon, ceramic or natural fibres; fillers which reduce the cost and improve the manufacturability of brake pads; and binder that holds the components together (Chrysoula, 2014).

It is reported that asbestos is carcinogenic (Dagwa and Ibhadode, 2005; Aigbodion et al., 2010; Idris et al., 2015). By the arrangements, particulate materials that gradually wear from brake pads, especially those from disc brakes are carried away by air into the environment. The health risks that the use of asbestos based brake pads pose have brought about the need to explore other non-asbestos based alternatives that would not expose users to any health risks as well as meeting the basic requirements of selecting materials for the friction lining of brake pads (Chand et al., 2012). Various agro-waste products have been used over the years to replace the asbestos content in brake pads; some of them are maize husk, palm kernel, bamboo stem, banana peelings, palm slag, periwinkle shell, coconut shell, oil palm shell, bagasse, etc.

Bashar et al. (2012) formulated brake pad with multi composite including ground coconut shell filler, epoxy resin binder matrix, iron chips reinforcement, methyl ethyl ketone peroxide 
catalyst, cobalt nephthanate accelerator, iron with silica abrasive and brass as friction modifier. The result showed that higher percentage coconut shell powder gave lower breaking, hardness, compressive and impact strengths, implying that increased coconut powder increased brittleness of pads. Idris et al. (2015) produced brake pads using banana peel to replace asbestos and varying phenol formaldehyde binder from 5-30\% at interval of $5 \%$. Result showed that compressive strength, hardness and specific gravity of samples increased with increased resin while, oil and water soak wear rate and percentage charred decreased with increased resin. Egg shell based eco-friendly brake pads was developed and evaluated by Edokpia et al., (2014); Abiodun et al., (2011); Adetan et al., (2007) with gum Arabic binder varied from 3-18\%. Wear rate, thickness swelling in water/oil, thermal resistance, specific gravity, compressive strength, hardness and micro-structural test results showed that samples with $18 \%$ gum Arabic gave optimum performances which compared favourably with commercial brake pads and that temperature of maximal decomposition was higher than asbestos and most agro-biomass based brake pads.

Fono and Koya (2013); Oladejo et al. (2007); developed automotive brake pad using palm kernel shell following the standard procedures employed by commercial manufacturers and the results obtained showed that the properties of palm kernel shell based brake pad satisfied the specifications of the Standard Organization of Nigeria (SON). Evaluation of brake pads developed from palm kernel fibres (PKFs) showed that the wear rate, coefficient of friction, noise level, temperature, and stopping time of the produced brake pads increased as the speed increases. The results also show that porosity, hardness, moisture content, specific gravity, surface roughness, and oil and water absorption rates remained constant with increase in speed.

Ikpambese et al. (2014) this review showed that researches all over the world today are focusing on ways of utilizing either industrial or agricultural wastes as sources of raw materials in the industry. These wastes utilization will not only be economical, but may also result in improved foreign exchange earnings and environmental control (Aigbodion et al. 2010). This research work evaluated bamboo leaf as a viable alternative to asbestos in brake pad production since bamboo has a higher compressive strength than wood, brick, or concrete and a tensile strength that rivals steel. It also contains element such as Calcium, Potassium and Iron in large quantity that are not harmful, in view of this it can be used to produce an eco-friendly and non- hazardous brake pad.

\subsection{Materials and Methods}

\subsection{Materials}

The raw materials used in the production of bamboo leaves brake pads were: filler (bamboo leaves), binder (epoxy resin and hardener), reinforcement (steel dust), solid lubricant (graphite), and frictional additive/modifier (silicon carbide, $\mathrm{SiC}$ ).

\subsection{Equipment}

The laboratory equipment used for the production of the test-samples are hammer milling machine (Model 000T), sieves (grade sizes 100 $\mu \mathrm{m}, 200 \mu \mathrm{m}$, and $350 \mu \mathrm{m}$ ), digital weighing scale, mixing pan, spatula, electric heater (220/240 Volts) and hydraulic press (maximum of $120 \mathrm{kN} / \mathrm{cm}^{2}$ capacity) (Model Pi00eh-Type, 100T-Capacity, Serial No-38280) located at Federal Institute of Industrial Research Oshodi (FIIRO) F.I.I.R.O Rd, Papa Ajao, Lagos, Nigeria.

\subsection{Chemical analysis of Bamboo leaves}

Chemical analysis of bamboo leaves was carried out to determine the proportion of the elements.

Chemical analysis of bamboo leaves shows that larger percentage of Calcium (205.57), Potassium (680.33) and Iron (70.57) $\mathrm{mg} / \mathrm{kg}$ are present while other trace elements are Copper (8.32), Manganese (3.17) and Chromium (0.19) $\mathrm{mg} / \mathrm{kg}$. 


\subsection{Preparation of raw samples}

Fresh leaves from a bamboo tree were collected and washed in order to remove contaminants and impurities. They were sun dried for four (4) weeks and cleaned. The leaves were ground into powder using a hammer mill and then sieved into different sieve sizes of aperture $100 \mu \mathrm{m}, 200 \mu \mathrm{m}$, and 350 $\mu \mathrm{m}$ in the brake lining formulation as shown in Figure 1 below.

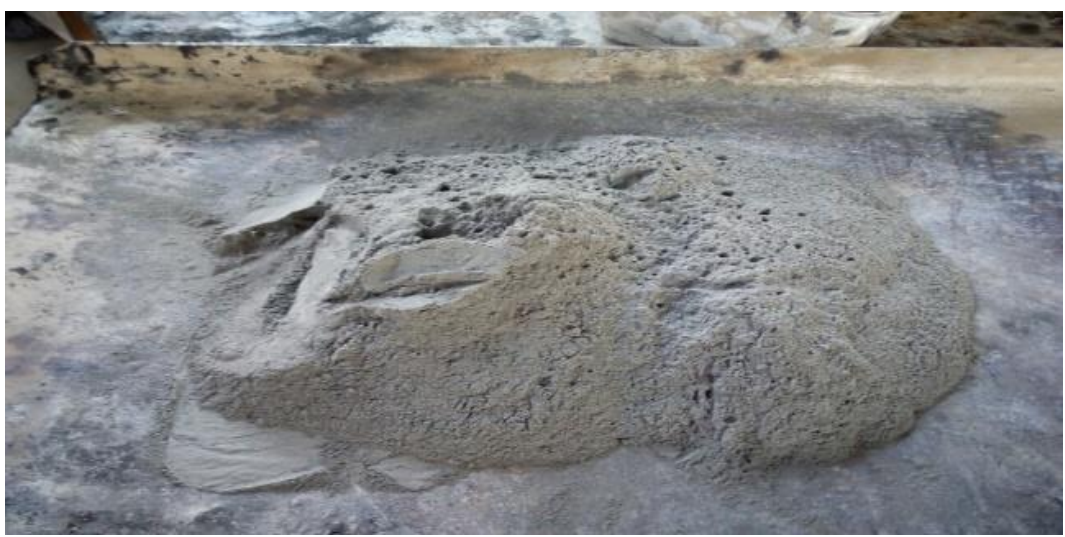

Figure 1: Ground and sieved sample of bamboo leaves.

\subsection{Method of production of brake pad samples}

Production of brake pad consists of a series of unit operations including mixing, cold and hot pressing, cooling, post-curing and finishing (Gurunath, 2007). The constituent ingredients, bamboo leaves, steel dust, graphite, silicon carbide, and resin. Different composition and sieve grades (i.e. $100 \mu \mathrm{m}, 200 \mu \mathrm{m}, 350 \mu \mathrm{m}$ ) of bamboo leaves, steel dust, graphite, silicon carbide powder and resin were added together in the ratio shown in Table 2 below. The combination was properly dry mixed in a mixer (Model 89.2 Ridsdale and Co ltd, Middlesbrough. Eng.) for 20 minutes until a homogenous component was formed and the mixture was transferred into a mould for cold pressing with a hydraulic press at $80 \mathrm{kN} / \mathrm{cm}^{2}$ and then conveyed into electric oven (Model Memmert, Western Germany) at a temperature of $150^{\circ} \mathrm{C}$ after which it was hot pressed at $100 \mathrm{kN} / \mathrm{cm}^{2}$ pressure for 2 minutes. After removing from hot mould, the brake pad was cured in an oven at a temperature of $120^{\circ} \mathrm{C}$ for 8 hours. The different composition variations led to the production of various samples with each sample weighing $100 \mathrm{~g}$ (i.e. samples A-E). Table 1 below shows the various compositions by mass of the various samples.

Table 1: Percentage composition (by mass) used in the production of samples of Bamboo leaves brake pads

\begin{tabular}{lllcccc}
\hline \multirow{2}{*}{ S/N } & \multirow{2}{*}{ Material } & \multicolumn{5}{c}{ Percentage composition (\%) by mass of material } \\
\cline { 2 - 6 } & & $\mathrm{A}$ & $\mathrm{B}$ & $\mathrm{C}$ & $\mathrm{D}$ & $\mathrm{E}$ \\
\hline 1. & Bamboo leaves & 35 & 40 & 45 & 50 & 55 \\
2. & Epoxy resin & 20 & 20 & 20 & 20 & 20 \\
3. & Steel dust & 15 & 15 & 15 & 15 & 15 \\
4. & Graphite & 10 & 10 & 10 & 10 & 10 \\
5. & Silicon carbide $(\mathrm{SiC})$. & 20 & 15 & 10 & 5 & 0 \\
\hline
\end{tabular}

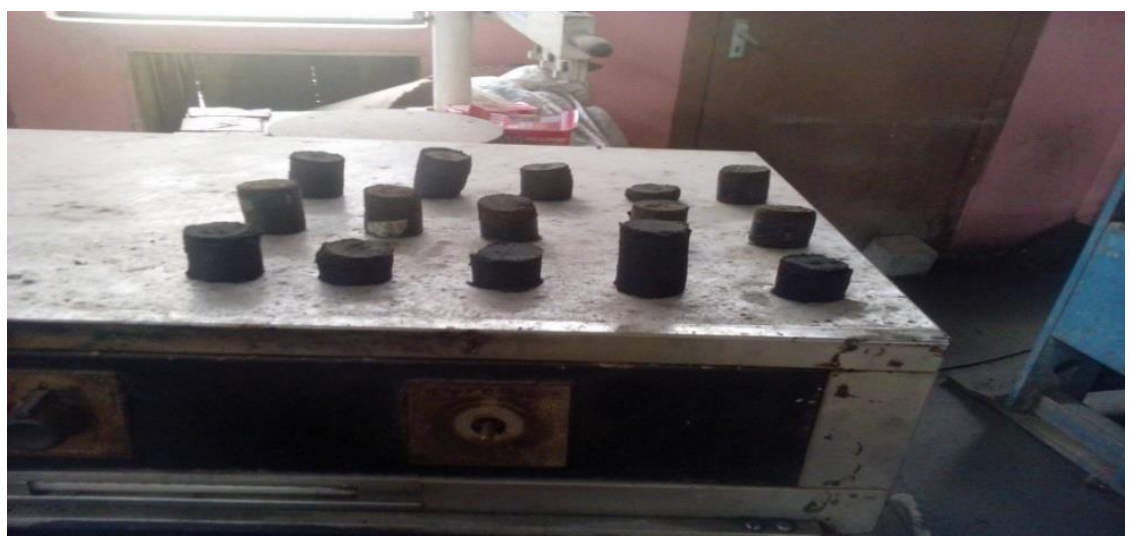

Figure 2: Plate of finished brake pad samples 


\subsection{Method of sample characterization}

\subsubsection{Brinell hardness Test}

The Brinell hardness values of the samples were obtained using a manual analog hardness tester. Four (4) disc-shaped samples of diameter $22.70 \mathrm{~mm}$ from each of the mixtures were tested under the Brinell hardness testing machine using a $10 \mathrm{~mm}$ diameter steel ball indenter with a load of $3000 \mathrm{kgf}$. The Brinell hardness number (HBN) of each of the samples was then calculated using the formula proposed by (Elakhame et al., 2014)

$$
H B N=\frac{2 P}{\pi D\left[D-\sqrt{D^{2}-d^{2}}\right]}
$$

\subsubsection{Compressive strength test}

The compressive strength was carried out using Hounsfield Tensometer. The four samples of diameter $22.70 \mathrm{~mm}$ were subjected to compressive force by loading them continuously until failure occurred. The loads at which each failure occurred were recorded while both the tensile stress and strain at this point were calculated using Equation (2) according to Elakhame et al. (2014).

$\sigma_{e}=\frac{F}{A_{0}}$

\subsubsection{Wear rate test}

The wear rate for the samples was measured using pin on disc machine by sliding it over a cast iron surface at loads of $10 \mathrm{~N}$ and $20 \mathrm{~N}$, sliding speed of $125 \mathrm{rev} / \mathrm{min}$ and sliding distance of $2000 \mathrm{~m}$. All tests were conducted at room temperature. The initial weight of the samples was measured using a single pan electronic weighing machine with an accuracy of $0.01 \mathrm{~g}$. During the test, the pin was pressed against the counterpart rotating against a cast iron disc (hardness 65 HRC) of counter surface roughness of $0.3 \mu \mathrm{m}$ by applying the load. A friction detecting arm was connected to a strain gauge held and the pin samples were vertically loaded into the rotating hardened cast iron disc. After running through a fixed sliding distance, the samples were removed, cleaned with acetone, dried, and weighed to determine the weight loss due to wear. The difference in weights measured before and after tests gave the wear of the samples (Aigbodion et al., 2010):

Wear rate $=\frac{\Delta s}{\mathrm{~W}}$

where:

$\Delta \mathrm{w} \quad$ Weight difference of the sample before and after the test in milligrams (mg)

$\mathrm{S} \quad$ Total sliding distance in metres $(\mathrm{m})$

\subsubsection{Density test}

The true density of the samples was determined by weighing the samples mass on a digital weighing machine and dividing by measuring their volume by liquid displacement method in accordance with Shehu et al. (2014).

$\rho=M / V$

\subsubsection{Porosity}

A sample of diameter $29.40 \mathrm{~mm}$ with a different height thickness of as thick as possible was used. The mass of specimen was weighed to the nearest $\mathrm{mg}$, and then soaked in oil and water container at $90-100^{\circ} \mathrm{C}$ for 8 hours. The samples were left for 24 hours and then taken out. Finally, the test samples were weighed to the nearest $\mathrm{mg}$. The porosity was determined as suggested by Elakhame et al. (2014).

$\rho=\frac{M_{2}-M_{1}}{D} \times \frac{100}{V}$ 
where:

$\rho \quad$ Density of test oil and water

$\mathrm{M}_{2} \quad$ Mass of test piece after absorbing oil and water $(\mathrm{g})$

$\mathrm{M}_{1} \quad$ Mass of test piece ( $\left.\mathrm{g}\right)$

$\mathrm{V} \quad$ Volume of test piece $\left(\mathrm{cm}^{3}\right)$

\subsubsection{Flame resistance test}

About $1.20 \mathrm{~g} \pm 0.1 \mathrm{~g}$ of the samples were weighed in a cooled crucible previously oven dried by heating in a furnace at $550^{\circ} \mathrm{C}$ for 1 hour. Then the samples were charred by heating in a hot plate, thereafter the charred samples were taken into the furnace and heated at $550^{\circ} \mathrm{C}$ for 1 hour. It was then cooled in a desiccator and weighed. This process of heating, cooling and reweighing was repeated until a constant weight was obtained.

$$
\begin{aligned}
& \% a s h= \frac{W_{2}-W_{0}}{W_{1}-W_{0}} \times 100 \\
& \text { Where: } \\
& \mathrm{W}_{0} \quad \text { Weight of empty crucible } \\
& \mathrm{W}_{1} \quad \text { Weight of crucible }+ \text { sample, and } \\
& \mathrm{W}_{2} \quad \text { Weight of crucible and residue i.e. after cooling. }
\end{aligned}
$$

\subsection{Results and Discussion}

\subsection{Chemical analysis of bamboo leaves}

The result of chemical analysis of bamboo leaves indicating the elements present is shown in Table 2. It shows that the major element in the bamboo leaves used is potassium followed by calcium, iron, while the trace elements present are manganese, copper and chromium.

Table 2: Chemical composition (by mass) of constituent element in bamboo leaves particles

\begin{tabular}{lc}
\hline Metals & Values $(\mathrm{mg} / \mathrm{kg})$ \\
\hline Calcium $(\mathrm{Cu})$ & 205.57 \\
Potassium $(\mathrm{K})$ & 680.33 \\
Manganese $(\mathrm{Mn})$ & 3.17 \\
Iron $(\mathrm{Fe})$ & 70.57 \\
Copper $(\mathrm{Cu})$ & 8.32 \\
Chromium $(\mathrm{Cr})$ & 0.19 \\
Nickel $(\mathrm{Ni})$ & 0.00 \\
\hline
\end{tabular}

\subsection{Brinell hardness test}

Figure 3, shows the results of Brinell hardness test carried out. It can be seen that as the sieve grade decreases, the hardness values of each sample increase. Sample size of $100 \mu \mathrm{m}$ had the highest hardness value of $258,237,231,226$, and $210 \mathrm{BHN}$ for samples A, B, C, D, and E respectively. This can be attributed to increase in surface area due to reduced particle size which allowed for increased binding ability with the resin. There is also a significant decrease in hardness values (as seen from Figure 2) of the samples of higher sieve grades (i.e. $200 \mu \mathrm{m}$ and $350 \mu \mathrm{m}$ ). The results obtained from the hardness test for this material (i.e. bamboo leaves) were better when compared with the standard, commercial (asbestos based) brake pads as shown in Table 3. As result of this $100 \mu \mathrm{m}$ or lower sieve grades are recommended for the production of the brake pad. 


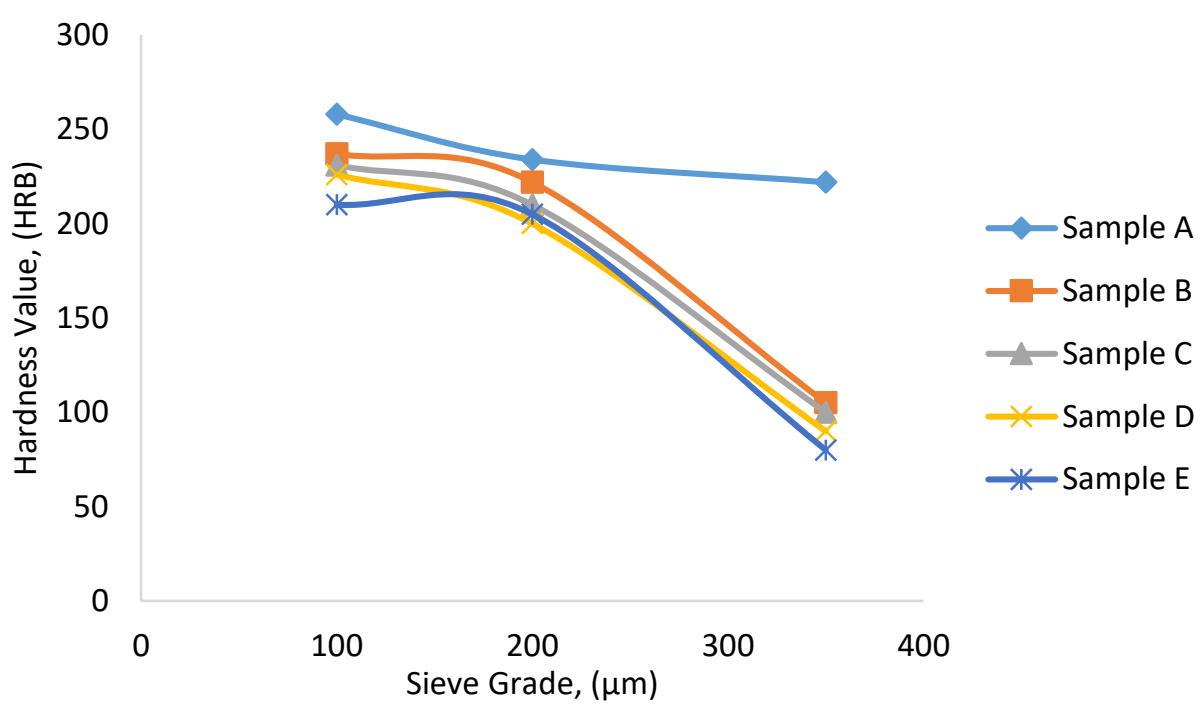

Figure 3: Variation of hardness values with sieve grades

\subsection{Compressive strength test}

Figure 4 shows the result of the compressive strength and peak values respectively for the produced samples with the sieve sizes. The $100 \mu \mathrm{m}$ sieve grade had the highest compressive strengths of 111 , 109, 107, 106 and 101 Mpa for samples A, B, C, D, and E respectively; and the highest peak values of 23.181, 25.614, 22.598, 22.287, and 21.293 $/ \mathrm{mm}^{2}$ for samples A, B, C, D, and E respectively. It can be observed that the peak values and compressive strengths of each sample decreases gradually as the sieve size increases; this is so because the surface area and pore packaging capability of the bamboo leaves particles in the resin are decreasing with increasing particle size. It can be clearly seen in the Figure 4 that $100 \mu \mathrm{m}$ sieve grade gives a better compressive strength.

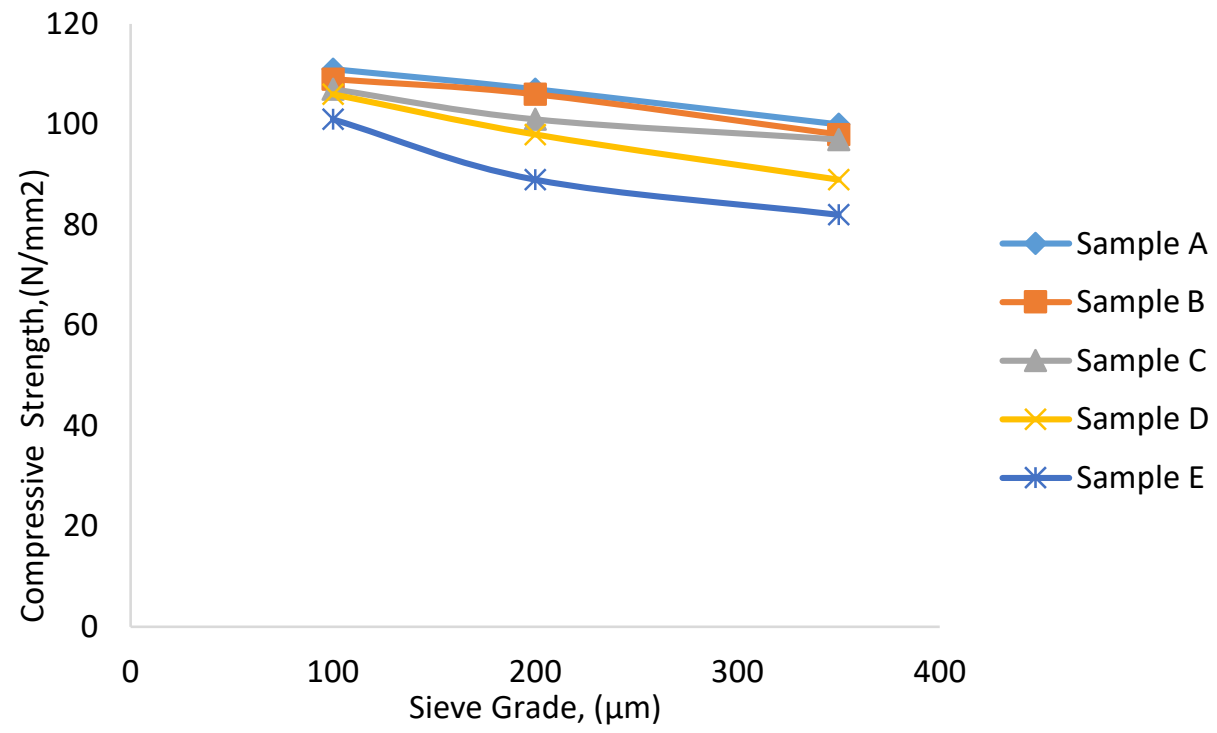

Figure 4: Variation of compressive strength with sieve grades

\subsection{Wear Rate Test}

The wear rates for the samples are presented in Figure 5 below, it can be seen that the sample wear rates increased as the particle size of the bamboo leaves increased and that the $100 \mu \mathrm{m}$ samples had the least wear rate values. This is due to the fact that smaller particles allow for higher or closer packaging which led to stronger binding of the bamboo leaves particles within the composition. This may also be due to the high hardness values and compressive strength of the samples obtained as the sieve size decreased which was in agreement with what was observed in Elakhame et al., 2014. In order to produce a durable and acceptable brake pad that will not fade away quickly, it is advisable to use $100 \mu \mathrm{m}$ samples with least wear property. 


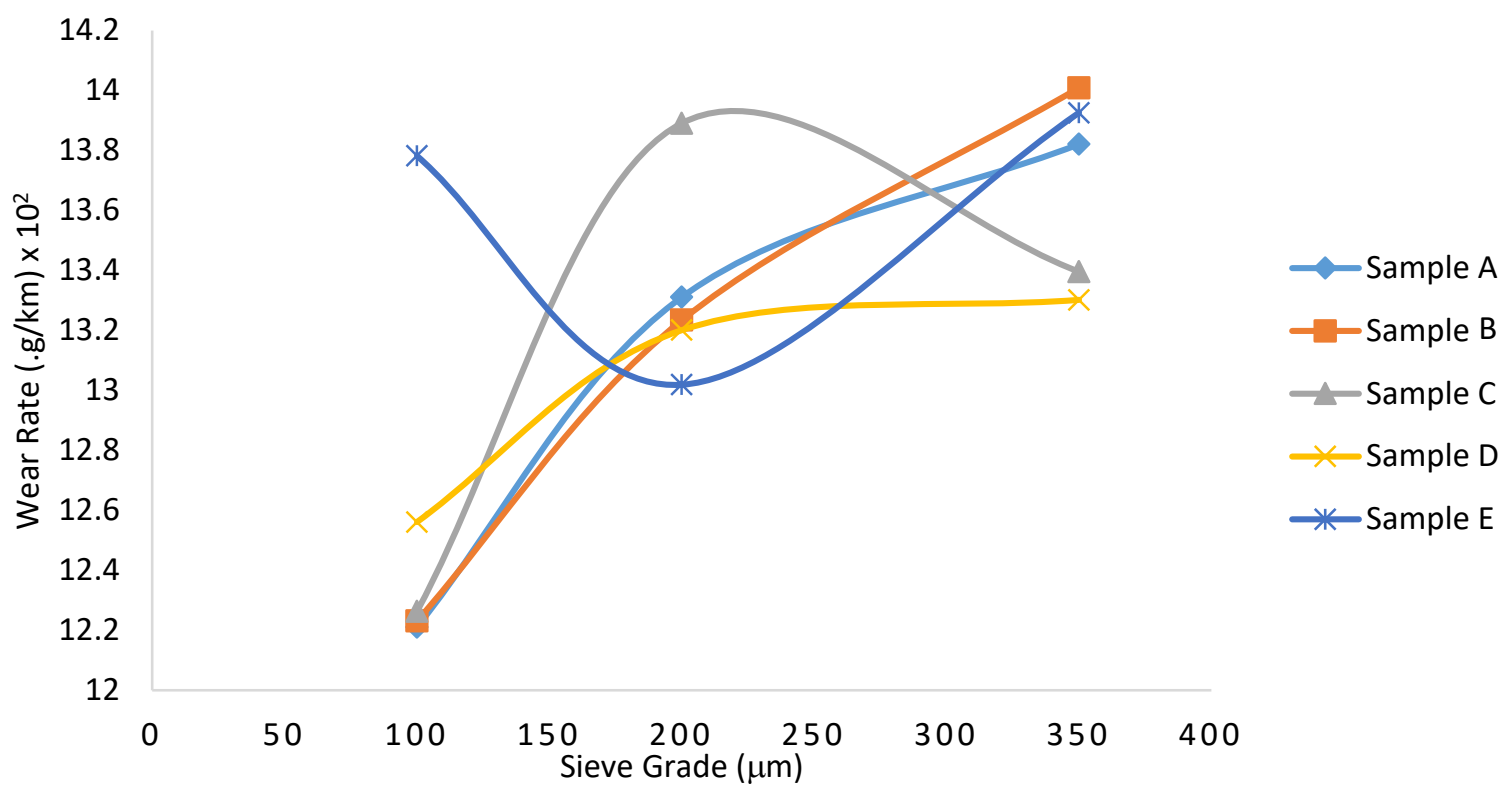

Figure 5: Variation of wear rates of samples produced with different sieve grade.

\subsection{Density Test}

Figure 6 shows graphical illustration of the plot of density against sieve grades of the samples and the density values generally increased as the percentage composition of bamboo leaves increased, this is due to the fact that the density of bamboo leaves increases as more and more of it is added to the composition of each sample which in turn increases the overall density of the samples. Furthermore, it was also observed that as the particle size of bamboo leaves increased, the density values decreased except for some isolated cases as seen in Figure 6. This is due to the fact that for smaller particles, the compressibility was higher because they were more porous i.e. the decrease in density can be attributed to the increase in particle size which allowed for increased packing. The $100 \mu \mathrm{m}$ had the highest density which was as a result of closer packing of bamboo leaves particles creating more homogeneity in the entire phase of the composite body. This result agrees with what was observed in Aigbodion et al. (2010). Due to better performance of sample produced with $100 \mu \mathrm{m}$ sieve grade, it is recommended that $100 \mu \mathrm{m}$ sieve grade can be considered in the production of brake pad using bamboo leaves.

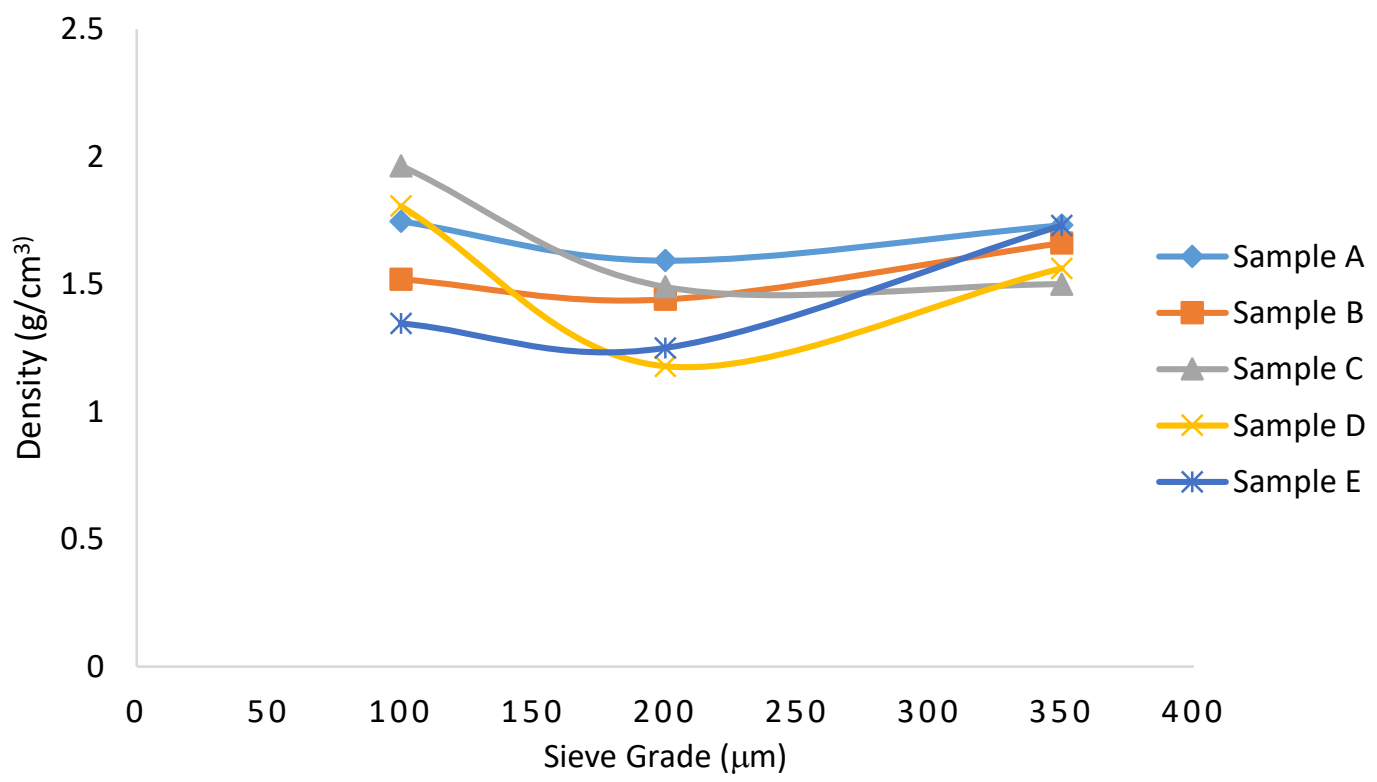

Figure 6: Variation of density with sieve grades 


\subsection{Flame resistance test}

The ash content properties of the produced samples increased as the sieve grade increased as shown in Figures 7. This can be attributed to the fact that as the particle size increases there is a corresponding increase in the pore sizes of the sample hence, for safety of vehicle, the brake pad should be made of smaller particles such as $100 \mu \mathrm{m}$ sieve grade or lesser grade particle sizes.

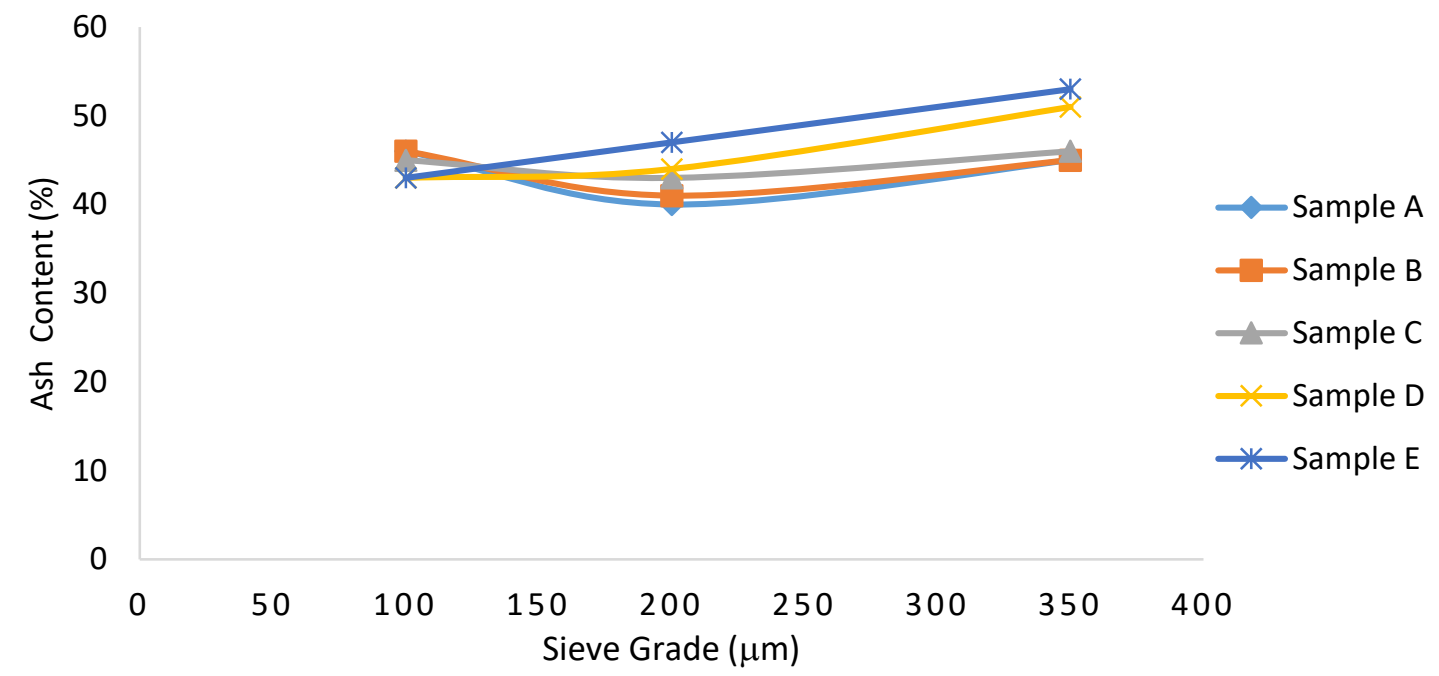

Figure 7: Variation of ash content with sieve grades

\subsection{Porosity Test}

Figure 8 shows the porosity test curves for the samples, the porosity of the produced samples increased as the sieve grade increased, this can be traced to the fact that there is an increase in the number and size of pores in the samples as the sieve size increases. It can be observed from Figures 8 , that sample with $100 \mu \mathrm{m}$ gave the best properties as a result of a very good dispersion of the bamboo leaves particles as seen in subsequent samples.

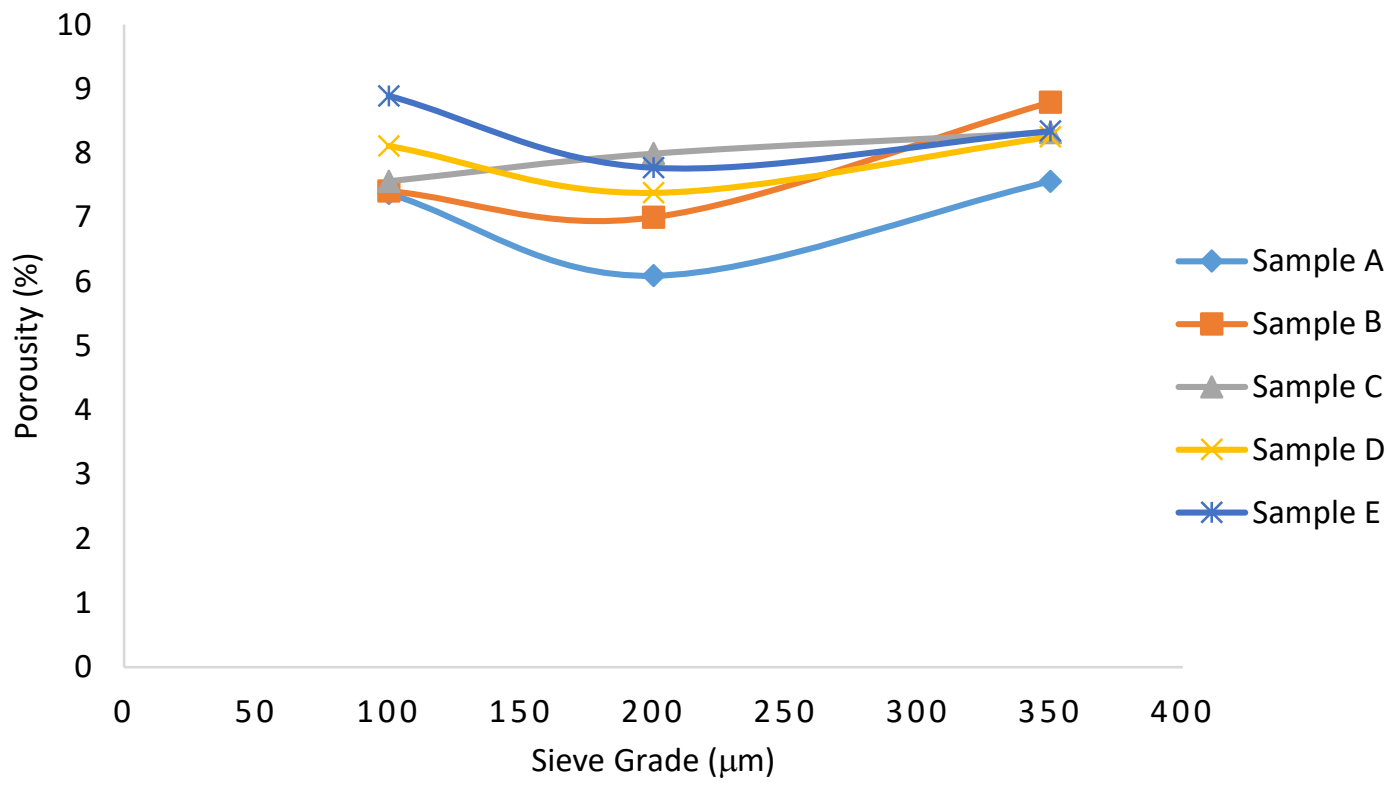

Figure 8: Variation of porosity (in water) with sieve grades. 
Table 3: Comparison between properties of asbestos brake pad and bamboo leaves brake pad produced.

\begin{tabular}{lcccccc}
\hline Properties & Commercial Brake Pads & Sample A & Sample B & Sample C & Sample D & Sample E \\
\hline Hardness (at 3000kgH) & 101 & 258 & 237 & 231 & 226 & 210 \\
Compressive strength $(\mathrm{MPa})$ & 110 & 111 & 109 & 107 & 106 & 101 \\
Average wear rate $\left(\mathrm{g} / \mathrm{km} \times 10^{-2}\right)$ & 3.800 & 12.211 & 12.231 & 12.263 & 12.561 & 13.782 \\
Density $\left(\mathrm{g} / \mathrm{cm}^{3}\right)$ & 1.320 & 1.746 & 1.519 & 1.964 & 1.806 & 1.346 \\
Porosity $(\%)$ in water & 0.52 & 7.37 & 7.41 & 7.56 & 8.11 & 8.89 \\
Flame resistance (\%) & Charred with 54\% ash & $46 \%$ ash & $46 \%$ ash & $45 \%$ ash & $43 \%$ ash & $43 \%$ ash \\
\hline
\end{tabular}

\subsection{Conclusions}

It could be concluded that samples with $100 \mu \mathrm{m}$ sieve grade of bamboo leaves generally gave the best properties in terms of compressive strength, hardness, and density. Based on the above test properties of these brake pads composite using bamboo leaves as filler, bamboo leaves could be used in the production of asbestos free brake pads if the wear rate and porosity properties of the produced samples could be improved.

\section{Acknowledgements}

The authors would like to acknowledge Department of Mechanical Engineering, Obafemi Awolowo University, and Department of Mechanical Engineering, Federal University of Agriculture, Abeokuta, Nigeria, for supporting the present work through Research Fund.

\section{References}

Abiodun, M. O., Adetan, D. A. and Oladejo, K. A, (2011), A Study of the Performance of Maize Starch based Cutting Fluids in the Turning of AISI 304 Stainless Steel, International Journal of Engineering Research in Africa, (JERA), 6, pp. 13-24, Switzerland.

Adetan, D. A. Adekoya, L. O. and Oladejo, K. A, (2007), An Improved Pole-and Knife Method of Harvesting Oil Palm, Agricultural Engineering International: the CIGR Ejournal, Vol. IX, Manuscript PM 06027. USA.

Aigbodion, V. S. Akadike, U., Hassan, S. B. Asuke, F. and Agunsoye, J. O, (2010). Development of Asbestos - Free Brake Pad Using Bagasse, Tribology in industry, 32(1), pp. 12-18.

Chand, N. Hashmi, A. R. Lomash, S. S. and Naik, A. (2012), Development of asbestos free brake pad $J M C, 85$, pp. 13-16.

Chrysoula, A. A., (2014). Composites in Automotive Applications: Review on brake pads and discs, Research Development: Literature Review, University of Bristol; November 12, pp. 1-13.

Bashar, D. A, Peter, B. M. and Joseph M., (2012), Material selection and production of a cold worked composite brake pad, World Journal of Engineering and Pure and Applied Sciences, 2(3), pp. 92-97.

Dagwa, I. M. and Ibhadode, A. O. A. (2005). Design and manufacture of experimental brake pad test rig, Nigerian Journal of Engineering Research and Development, 4(3), pp. 15-24.

Edokpai, R. O. Aigbodion, V. S. Obiorah, O. B. and Atuanya C. U. (2014), Evaluation of the Properties of Ecofriendly Brake Pad Using Egg Shell Particles-Gum Arabic, Science Direct, Elsevier B.V. DOI: 10.1016/j.rinp.2014.06.003.

Elakhame, Z. U., Alhassan, O. A. and Samuel; A. E. (2014). Development and Production of Brake Pads from Palm Kernel Shell Composites. International Journal of Scientific and Engineering Research, 5(10), pp. 735-744.

Fono-Tamo, R. S. and Koya, O. A. (2013). Characterization of Pulverized Palm Kernel Shell for Sustainable Waste Diversification, International Journal of Scientific and Engineering Research, 4(4), pp. 6-10. 
Idris, U. D. Aigbodion, V. S. Abubakar, I. J. and Nwoye, C. I, (2015). Eco-friendly asbestos free brake-pad: Using banana peels, Journal of King Saud University - Engineering Sciences, 27, pp. 185192.

Ikpambese, K. K. Gundu, D. T. and Tuleun; L. T. (2014). Evaluation of palm kernel fibers (PKFs) for production of asbestos-free automotive brake pads, Journal of King Saud University Engineering Sciences, pp. 1-9

Oladejo, K. A, Olaniyan, A, Obayopo, S. O, and Abu, R, (2007), Computer-Based Simulation in Thermal Energy Education and Research, Proceedings of the $20^{\text {th }}$ National Mechanical Engineering Conference, pp. $81-89$, Kaduna, Nigeria.

Shehu, U., Aponbiede, O., Ause, T. E. and Obiodunukwe, F., (2014). Effect of particle size on the properties of Polyester/Palm Kernel Shell (PKS) Particulate Composites, J. Mater. Environ. Sci., 5(2), pp. 366-373.

Osterle, W., Griepentrog, M., Gross, T. and Urban. I (2001) Chemical and microstructural changes induced by friction and wear of brakes, Wear, 251, pp. 1469-1476. 